\title{
Substrate Recognition by Sugar Chain-Related Enzymes: Recognition of a Large Area of Substrates and Its Strictness and Tolerance
}

\author{
糖鎖関連酵素の基質認識 一基質の広い領域の認識とその厳密性、寛容性一 \\ Ishimizu, Takeshi ; Hase, Sumihiro \\ Department of Chemistry, Graduate School of Science, Osaka University \\ Machikaneyamacho 1-1, Toyonaka, Osaka 560-0043, Japan \\ FAX: 81-6-6850-5383, E-mail: txi@chem.sci.osaka-u.ac.jp \\ Key Words: substrate recognition, glycosidase, glycosyltransferase, sugar chain, pyridylamination
}

\begin{abstract}
Analysis of the substrate specificity of some sugar chain-related enzymes using homogeneous sugar chains (mainly fluorescently labeled sugar chains) can reveal the in vivo substrate of the enzyme. Such analyses have shown that these enzymes have the ability to recognize not only the sites of hydrolysis or glycosyl transfer but also other regions far apart from them. They can recognize a region consisting of pentasaccharides, hexasaccharides and, in some cases, decasaccharides or larger saccharides. The enzymes recognize part of the substrate strictly, and another part of it tolerantly. These analyses have also identified pairs of enzymes with substrate specificities that are complementary to each other. Here we describe some sugar chain-related enzymes with these properties. The biological significance of the recognition of a large substrate area and its strictness and tolerance will be discussed.
\end{abstract}

要 約

化学的に均一な糖鎖 (主に蛍光ラベルされた糖鎖) を用い たいくつかの糖鎖関連䤃素の基質特異性解析は、酵素の生体 内での基質を明らかにする。その解析により、酵素が加水分 解部位あるいは糖転移部位のみならず、その部位からかなり 離れた基質部分も認識する場合のあることが明らかになって きた。 5 糖、6 糖、場合によっては 10 糖以上の単位で糖鎖を 認識し、ある部分は厳密に、ある部分はあいまいに認識して いる。また基質特異性が相補的な酵素の組み合わせがあるこ とも明らかになってきた。これらの一例を記述し、糖鎖関連 酵素の㛜密なそして寬容な広い領域の基質認識の生物学的意 義について議論したい。

\section{A. Introduction}

Glycosidases and glycosyltransferases involved in the degradation and biosynthesis of sugar chains have long been studied, and enzymes bearing novel substrate specificities continue to be discovered today. The glycosidases and glycosyltransferases are named according to their specificity for sites of hydrolysis and glycosyl transfer, respectively, on the substrate. They are systematically categorized by an EC number (based on their substrate specificity) (1) or a CAZY number (based on their structure) (2). During the analysis of these enzymes, the following experiments are often carried out: construction of an assay method; extraction and purification of the enzyme from living cells; analysis of substrate specificity; molecular cloning of the corresponding gene; tertiary structural analysis; and functional analysis using a knockout mutant. Of these experiments, analysis of substrate specificity characterizes the enzymes and provides important information on their biological significance.

For the assay of sugar chain-related enzymes, substrates reflecting the names of enzymes are usually used.

\section{A. はじめに}

糖鎖の分解、生合成に関わる糖加水分解酵素、糖転移酵 素は古くから研究され、現在もこれまでに知られていなかっ た基質特異性をもつ酵素が発見され続けている。糖加水分解 醰素、糖転移酵素の名称は加水分解部位あるいは糖転移部位 の基質特異性を反映したものになっている。それらは EC 番号 (基質特異性に基づく)(1) や CAZY 番号 (構造情報に基づく)(2) によって系統的に分類されている。研究手法として、活性測 定法の確立、生体試料からの抽出・精製、基質特異性解析、 遺伝子クローニング、立体構造解析、対応遺伝子の発現打破 変異体の機能解析などが行われる。中でも酵素の基質特異性 は、その酵素を特徴づけると共に、生物学的意味を探る上で 重要な情報となる。

糖鎖関連酵素の活性測定の基質には、その酵素の名称を反 映するようなものが用いられる。実際には、基質調製や生成 
Simple substrates that differ from the native substrates of the enzymes are often used in practice, in order to facilitate easy preparation of the substrates and analysis of the products. For the assay of exo-type glycosidases, for example, $p$-nitrophenyl derivatives of monosaccharides are often used as substrates. Similarly, heterogeneous polysaccharides are generally used as substrates for the assay of endo-type glycosidases. In addition, derivatives of monosaccharides or disaccharides that retain the structure of the site of glycosyl transfer are often used for the assay of glycosyltransferases. Although analyses using such substrates are convenient and quick, the substrates do not always reflect the in vivo substrates of the enzymes. Analyses with such substrates cannot satisfy an analysis of the substrate specificity of an enzyme. Instead, it is necessary to prepare homogeneous sugar chains, which are considered to be the in vivo substrates of the enzymes. Analysis of substrate specificity using homogeneous sugar chains can specify the true substrates of an enzyme in a cell and can also provide
産物の解析の簡便さが求められるため、生体内での基質の構 造とは離れた比較的簡単な構造のものが用いられる。例えば、 エキソ型の糖加水分解酵素では、対応する単糖のパラニトロ フェニル誘導体がよく用いられる。エンド型の糖加水分解酵 素では、基質の構造が不均一な多糖が用いられることが多い。 糖転移酵素の場合、ターゲットにしている糖転移部位の構造 を保持した単糖や二糖の誘導体が用いられていることが多い。 これらの基質を用いた活性測定は、簡便さや迅速性は備えら れるが、必ずしも生体内での基質を反映しているとは限らず、 酵素の基質特異性解析の観点からは、不十分である。基質特 異性を解析するには、実際の生体内での基質と考えられる、 化学的に均一な一連の糖鎖を揃える必要がある。それらの一 連の糖鎖を用いた基質特異性解析は、生体内での酵素の基質 を特定することにつながり、簡便な基質を用いた解析では明

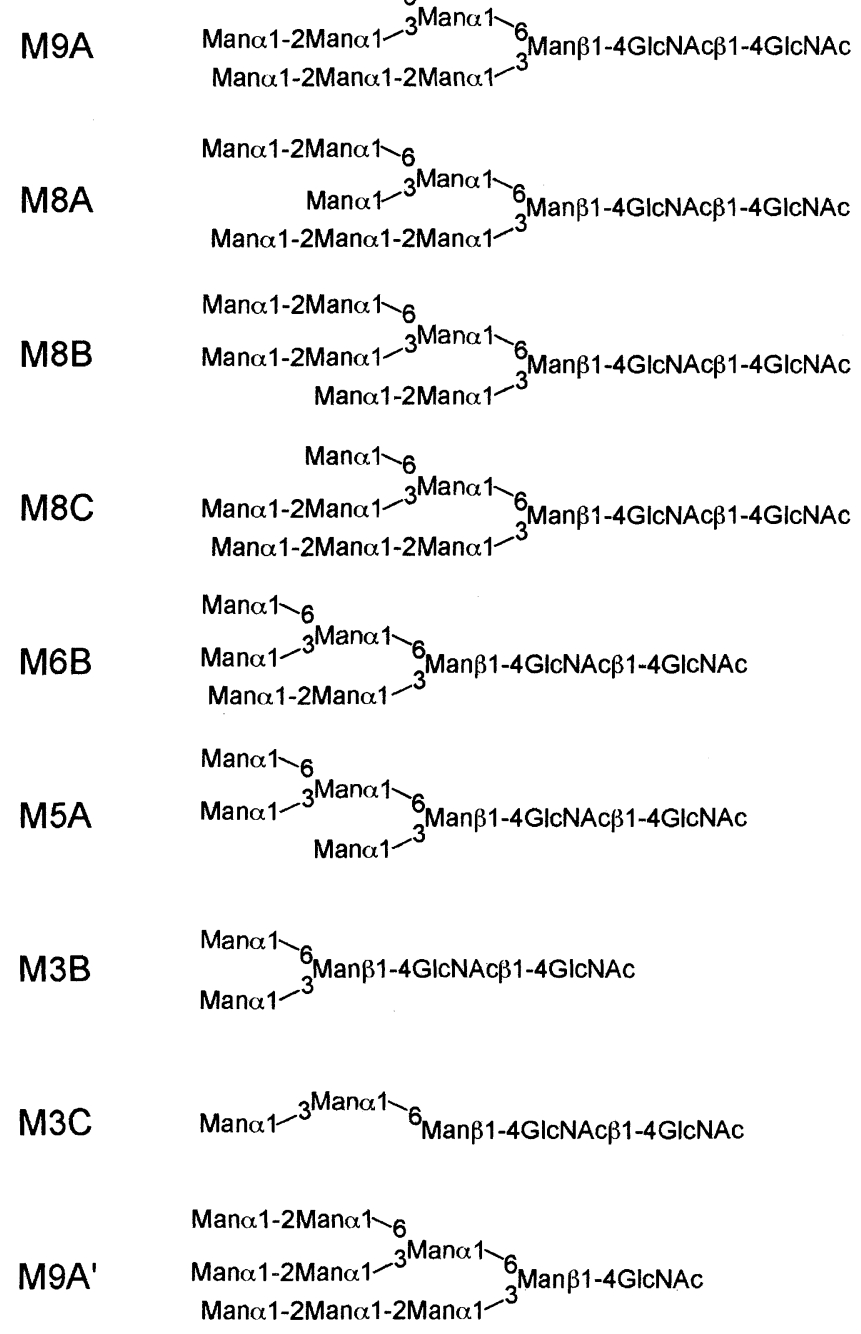

Man $\alpha 1-3^{\operatorname{Man} \alpha 1}-{ }_{6}$ Man $\beta 1-4$ GlcNAc $\beta 1-4$ GICNAC $\quad$ BiF

M8A'

M5B'

Bi

BiB

BA-2

BA-1

Tri

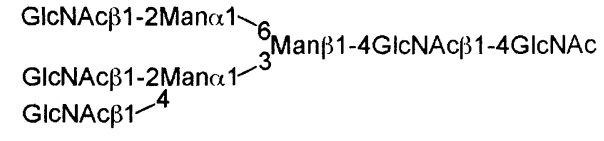

Fig. 1. Structures and abbreviations of sugar chains used in this article. 
information about the function of sugar chain-related enzymes and/or sugar chains. Their functions cannot be predicted from analyses using simple substrates.

In this review, first we outline the methods for preparing homogeneous sugar chains for the analysis of substrate specificity. Then, we describe analysis of the substrate specificity of some sugar chain-related enzymes. This type of analysis has shown that the enzymes act on a large area of their substrates and that they recognize a part of the substrate strictly and another part of it tolerantly.

The structures and abbreviations of the sugar chains described in this article are listed in Fig. 1.

\section{B. Preparation of Sugar Chains as Substrates \\ B-1. Preparation of Glycopeptides}

One method for preparing homogeneous sugar chains used for the analysis of substrate specificity is chemical synthesis. Several $N$-linked sugar chains have been successfully chemically synthesized. One of the reasons for this success has been the establishment of a synthetic method (including enzymatic synthesis) for $\beta$-mannoside (3), for which stereochemical control is difficult to achieve during chemical synthesis. Homogeneous glycopeptides are required for analysis of the substrate specificity of the sugar chainrelated enzymes that act on glycoproteins. Glycopeptides derived from natural glycoproteins are normally structurally heterogeneous. Because a separation method for natural glycopeptides has not been established, a chemical synthetic method has proved especially effective for the preparation of homogeneous glycopeptides.

Glycopeptides have been recently synthesized by solid-phase synthesis using glycosylated amino acids (4, 5). Deacetylation of a glycopeptide in which the hydroxyl groups are blocked with acetyl groups can be conducted under alkaline conditions, but the deacetylation step is accompanied by $\beta$-elimination of $O$-linked sugar chains, epimerization of the $\alpha$-carbon of the amino acid, and transfer of the acetyl group to the $\alpha$-amino group of the terminal amino acid of a polypeptide on the solid-phase. However, solid-phase synthesis of glycopeptides has been accomplished by using glycosylated amino acids whose hydroxyl groups are blocked with benzyl groups, and by subsequently debenzylating either with catalytic hydrogenation (6) or under low acidic conditions $(7,8)$. Solid-phase synthesis of glycopeptides using Fmoc amino acid attached sugar chains in which the hydroxyl groups are free has been accomplished by incorporating a mild coupling method using pentafluorophenylester (9-12) or benzotriazolylester (13-16). By this method, glycopeptides consisting of more than 40 amino acid residues have been synthesized $(15,16)$, and preparation of glycopeptides by the Fmoc method has been put to practical use.
らかにならなかった糖鎖関連酵素および糖鎖の生体内での機 能についての情報をもたらす。

本稿ではまず、糖鎖関連酵素の基質特異性解析に用いる均 一な糖鎖の調製法について概説する。次いで、糖鎖関連酵素 の基質特異性解析の例を紹介する。それらの解析により、い くつかの糖鎖関連䤃素が基質の広い領域に作用し、ある部分 は厳密に、ある部分は寛容に認識していることが明らかになっ てきた。

なお、本稿中で用いる糖鎖構造の略号とそれらに対志する 構造を図 1 に示す。

\section{B. 糖鎖基質の調製}

\section{B-1. 糖ペプチド基質の調製}

糖鎖関連酵素の基質特異性解析に用いる均一な糖鎖基質 の調製法の一つは化学合成によるものである。 $N$ - 配糖体糖鎖 を例に挙げると、合成時の立体化学制御が困難な $\beta$-マンノシ ル結合の実際的な合成手法 (酵素的方法も含めて)(3) が考案さ れたこともあり、多くの $N$ - 配糖体糖鎖の合成が可能になって きている。糖タンパク質に作用する糖鎖関連酵素の基質特異 性研究では、均一な糖ペプチドを必要とする場合がある。天 然の糖タンパク質由来の糖ペプチドは、通常は糖鎖部分の構 造に不均一性がある。それらの糖ぺプチドの分離法が確立さ れていないため、糖ペプチドの調製は、化学合成による方法 が特に有効である。

近年、糖アミノ酸を用いた固相合成によって、糖ペブチ ドの合成が行われるようになってきた $(4 、 5)$ 。糖の水酸基がつ セチル基で保護された糖ぺプチドの脱アセチル化は塩基性条 件下で行われるが、 $O$-配糖体の $\beta$ - 脱離、アミノ酸 $\alpha$ 炭素上 でのエピメリ化、固相上のポリペプチド鎖の末端の $\alpha$-アミ 基へのアセチル基の転移が伴う。しかし、糖の水酸基をべン ジル基で保護した糖アミノ酸をビルディングブロックとして 用い、脱ベンジルの際、接触水素化 (6) あるいは低酸性条件下 (7、8) で行うことで、糖ペプチドの固相合成が達成された。ま た水酸基が保護されていない糖を結合した Fmocアミノ酸を用 いた固相合成は、ペンタフルオロフェニルエステル (9-12) あ るいはベンゾトリアゾリルエステル (13-16) を用いた穏やかな カップリング法を用いることで達成されている。この方法に よるとアミノ酸 40 残基以上からなる糖ぺプチドの合成も可能 で $(15 、 16) 、 F m o c$ 法による糖ぺプチドの合成が実用的なもの となってきている。 
Using the transglycosylation activity of endo- $\beta-N$ acetylglucosaminidase from Mucor hiemalis (Endo-M), complex or high-mannose type sugar chains can be introduced to glycopeptides bearing $\mathrm{N}$-acetylglucosamine at an asparagine residue (17). A homogeneous complex-type sugar chain attached to asparagine has been prepared from a natural source at the $100-\mathrm{mg}$ scale (18). Using this glycosylated amino acid, a glycopeptide bearing sialic acid, which is labile under acidic conditions, has been synthesized by this method (19). Furthermore, the glycosylated amino acid has been digested by exoglycosidases to obtain a dozen homogeneous complex-type sugar chains attached to asparagine, and their corresponding glycopeptides have also been synthesized (20, 21).

The synthetic glycopeptides have been used for studying the glycosyltransferases involved in the synthesis of sugar chains attached to a specific peptide. For example, the EGF-like domains of serum proteins such as blood coagulation factors contain the specific sugar chain, Xyl $\alpha 1-3 \mathrm{Xyl} \alpha 1$ $3 \mathrm{Glc} \beta$, at a serine residue in the consensus sequence (22). The synthetic EGF-like domains in which Glc or Xylo1-3Glc is attached at a serine residue $(15,16)$ are useful for analyzing the substrate specificity of the xylosyltransferases involved in biosynthesis of this sugar chain.

In summary, glycopeptides can be chemically synthesized in principle; however, procedures such as protection and deprotection are complicated, and it is still laborious work to prepare the many glycopeptides required for analyzing the substrate specificity of an enzyme.

\section{B-2. Separation and Preparation of Pyridylaminated Sugar Chains as Substrates}

A second method of obtaining homogeneous sugar chains to use as substrates is to prepare them from natural resources. In this approach, the sugar chains are prepared as their pyridylamino derivatives because these derivatives are well resolved by HPLC, especially reversed-phase HPLC. Sugar chains are liberated from glycoproteins by hydrazynolysis, and then the reducing ends of the sugar chains are pyridylaminated by reductive amination (23). If necessary, these sugar chains can be hydrolyzed by using exoglycosidases with known substrate specificities to obtain the targeted sugar chains. Most pyridylaminated sugar chains can be separated by normal phase (size fractionation) and reversedphase HPLC, and dozens of homogeneous sugar chains can be prepared at a time. As methods for pyridylamination of sugar chains have been reviewed elsewhere $(24,25)$, below we describe practical methods for preparing pyridylaminated sugar chains as substrates for enzyme assay and for separating pyridylaminated sugar chains on HPLC.

To obtain a homogeneous sugar chain, it is convenient to use easily obtainable glycoproteins that bear the targeted
また Mucor hiemalis 由来のエンド - $\beta-N-$ アセチルグルコサ ミニダーゼ(Endo-M)のトランスグリコシレーション活性を用 いて、N-アセチルグルコサミンをもつ糖ペプチドにコンプレッ クス型糖鎖やハイマンノース型糖鎖を導入することができる (17)。天然から $100 \mathrm{mg}$ スケールでアスパラギンに結合したシ アル酸含有コンプレックス型糖鎖を調製し (18)、それを用い て酸に不安定なシアル酸を含む糖ぺプチドもこの方法により 合成された(19)。またそのように調製されたコンプレックス 型糖鎖をエキソグリコシダーゼで処理し、十数種類の糖鎖を 得て、それぞれに対応する糖ぺプチドの合成が達成されてい る $(20 、 21)$ 。

これらの合成糖ペプチドは、ある特異な構造のペプチド上 に結合した糖の生合成に関わる糖転移酵素の基質特異性研究 に用いることができる。例えば、血液凝固因子などの血清夕 ンパク質の EGF 様ドメインのコンセンサス配列上のセリン残 基に特異的に Xyl $\alpha 1-3 \mathrm{Xyl} \alpha 1-3 \mathrm{Glc} \beta$ という糖鎖が結合している (22)。合成された Glc あるいは Xyl $\alpha 1-3 \mathrm{Glc}$ が特定のセリン残 基に結合した EGF 様ドメイン $(15 、 16)$ は、この糖鎖の生合成 に関与するキシロース転移酵素の基質特異性解析に有用であ る。

このように、糖ペプチドは原理的には化学合成されるよう になってきたが、保護・脱保護のプロセス等、操作が煩雑で あり、酵素の基質特異性解析で必要とされる一連の数種の糖 ペプチドを一度に調製するのは、まだ困難な仕事である

\section{B-2. ピリジルアミノ化糖鎖基質の分離と調製}

均一な糖鎖基質の調製のもう一つの有効な方法は、生物試 料から糖鎖を得ることである。逆相 HPLC 上での分離が特に 優れていることから、ピリジルアミノ化誘導体として糖鎖を 調製する。糖タンパク質からヒドラジン分解により糖鎖部分 を切り出し、次いで糖鎖の還元末端を還元アミノ化反応によ りピリジルアミノ化する(23)。必要に応じて、基質特異性が 明らかなエキソ型グリコシダーゼを用いて加水分解し、目的 の糖鎖を得る。ほとんどのピリジルアミノ化糖鎖は順相(サイ ズ分画) HPLC および逆相 HPLCにより分離され、複数種類の 均一な糖鎖を一度に調製できる。糖鎖のピリジルアミノ化に ついてはこれまでに解説がなされているので、そちらを参照 されたい $(24 、 25)$ ここでは、酵素基質としてのピリジルアミ ノ化糖鎖の調製の実際とその HPLCにおける分離について触 れる。

均一な糖鎖を得るためには、調製しやすく、欲しい糖鎖 を主に持っている糖タンパク質があると都合がいい。これら 
sugar chain as a major chain. Glycoproteins that fulfill these requirements include $\operatorname{IgY}(26)$, riboflavin binding protein (27), ovomucoid (28), Taka-amylase A(29, 30), and fetuin (31) among others. The structures of sugar chains prepared from these glycoproteins are shown in Fig. 2. Several high-mannose type sugar chains can be prepared from the globulin fraction (soluble proteins in salt solution) of kidney bean (Phaseolus vulgaris) without the need to purify the glycoproteins (our unpublished data). Furthermore, sialyl complex-type sugar chains can be prepared from hen egg yolk (18). Pyridylaminated sugar chains can be prepared from these samples, and separated and purified by size fractionation and reversed-phase HPLC. They can be purified by these types of HPLC because several hundred pyridylaminated sugar chains each have a unique retention time on these two HPLC columns (32-34). By contrast, sugar chains that are not found in natural resources can be obtained by exoglycosidase digestion or partial acid hydrolysis of the sugar chains that are available. Typical examples of the separation and preparation of high-mannose and complex type sugar chains are described below.

To elucidate the processing pathway of high-mannose type sugar chains, a quantitative analysis of each isomer of the high-mannose type sugar chains is required. Generally, it is difficult to separate and purify every isomer of $\mathrm{N}$-linked sugar chains, but 21 kinds of pyridylaminated high-mannose type sugar chains including structural isomers have been clearly separated by size fractionation and reversed-phase HPLC $(35,36)$. For preparation of the M9 and M8 isomers (their structures are shown in Fig. 1), M9A and M8A are prepared from soybean agglutinin (37) and Japanese quail ovalbumin (38), respectively. M8B and M8C, which are not obtained easily from natural resources, can be prepared by the partial digestion of M9A with Aspergillus oryzae $\alpha-1,2$-mannosidase

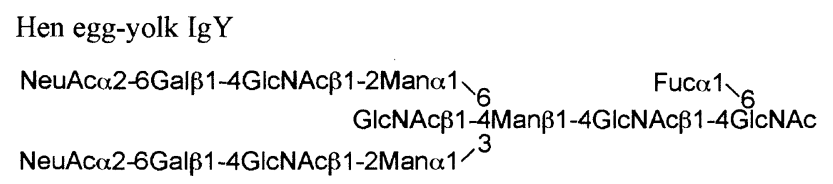

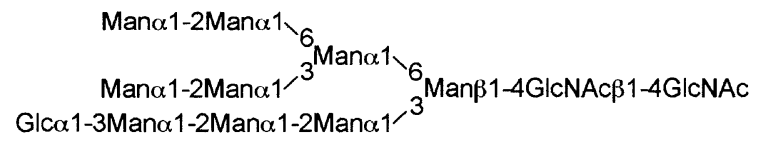

Hen egg-yolk riboflavin binding protein NeuAc $\alpha 2-6$ Gal $\beta 1-4 G I c N A c \beta 1-2 M a n \alpha 1$
NeuAc $\alpha 2-6$ Gal $\beta 1-4 G I c N A c \beta 1-2 M a n \alpha 1$
の要件を満たす糖タンパク質として、IgY(26)、リボフラビン 結合タンパク質 (27)、ウズラオボムコイド (28)、タカアミラー ゼA (29、30)、フェツイン (31) などがある。これらの糖タンパ ク質から調製される糖鎖の構造を図2 に示す。また、糖タン パク質を精製せず、大福豆(白インゲン豆：Phaseolus vulgaris) のグロブリン画分 (塩溶液に可溶なタンパク質) から各種ハイ マンノース型糖鎖を調製することもできる(未発表データ)。 卵黄からシアル酸を含むコンプレックス型糖鎖を調製するこ ともできる $(18)$ 。これらの試料からピリジルアミノ化糖鎖を 調製し、サイズ分画 HPLC と逆相 HPLC などで分離、精製する。 数百のピリジルアミノ化糖鎖のサイズ分画 HPLC と逆相 HPLC の保持時間はそれぞれに固有の值を与える (32-34)ため、精 製が可能である。必要な糖鎖が天然に主成分として含まれな い場合は、入手できる糖鎖のエキソグリコシダーゼ消化ある いは部分酸加水分解を行うことにより得る。以下に例として、 ハイマンノース型やコンプレックス型糖鎖の分離と調製につ いて述べる。

ハイマンノース型糖鎖のプロセッシング経路を明らかに するためには、ハイマンノース型糖鎖の各種異性体の定量的 な解析が必要である。 $N$ - 配糖体糖鎖の各異性体を分離、精製 するのは難しいが、ピリジルアミノ化されたハイマンノース 型糖鎖はサイズ分画、逆相 HPLCにより、各異性体 (21 種類) がきれいに分離できる $(35 、 36)$ 。M9、M8の異性体( 各糖鎖の 構造は図 1 参照) のみ例を挙げると、大豆アグルチニン (37) から M9A、ウズラオボアルブミン (38) から M8A が調製できる。 天然の糖タンパク質から得られにくいM8B、M8CはM9Aを 教菌 $\alpha-1,2-$ マンノシダーゼにより部分加水分解することで得 られた (35)。M8の3つの異性体、M8A、M8B、M8Cを逆相 HPLCにより 20 分以内で完全に分離できる (35)。このことを

Japanese quail egg-white ovomucoid

Mano1 Man $\alpha 1^{-3}$

${ }^{6} \mathrm{Man} \beta 1-4 \mathrm{GlcNAc} \beta 1-4 \mathrm{GlcNAC}$

Taka-amylase A

Mano1

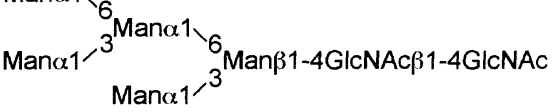

Bovine fetuin NeuAc $\alpha 2-3$ Gal $\beta 1-4 G \mid c N A c \beta 1-2 M a n \alpha 1 \backslash_{6}$

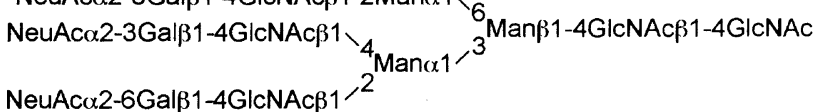

Fig. 2. Sugar chains prepared from natural glycoproteins. The structures of major sugar chains attached to glycoproteins are shown. 


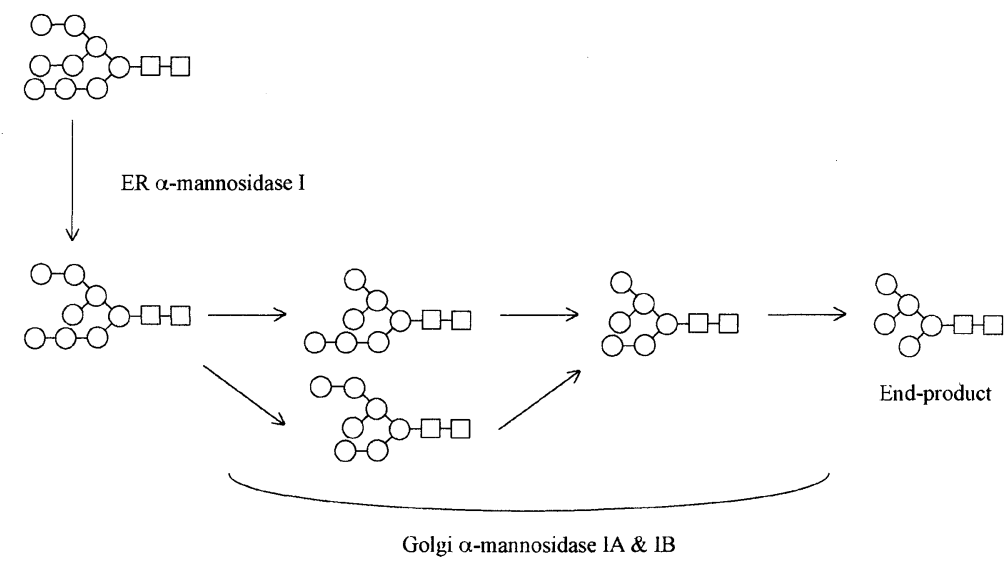

Fig. 3. Processing pathway of high-mannose type sugar chains by the co-operative action of ER $\boldsymbol{\alpha}$-mannosidase I and Golgi $\alpha$-mannosidases IA and IB. Circles and squares represent mannose and $\mathrm{N}$-acetylglucosamine residues, respectively.

(35). Three isomers of M8 high-mannose type sugar chains can be separated by reversed-phase HPLC within 20 min (35). This separation of M8 isomers has been applied to analyze the substrate specificity of ER and Golgi $\alpha$-mannosidases. Removal of mannose from M9A by the ER $\alpha$-mannosidase I leads to the isomer M8A (39), which in turn is the most favorable substrate for the Golgi $\alpha$-mannosidases IA and IB (40) (Fig. 3), meaning that the substrate specificities of these $\alpha$-mannosidases are complementary to each other. The Golgi $\alpha$-mannosidases IA and IB hydrolyze the $\alpha-1,2$-mannoside linkages of M8A to give M5A as an end product (40).

Even if multiple products are produced from a homogeneous substrate by an enzyme, the products can be identified from their retention time of HPLC. For example, the $\mathrm{N}$-acetylglucosaminyltransferases III, IV, and V transfer $\mathrm{N}$-acetylglucosamine to the mannose residues of the sugar chain, $\mathrm{Bi}$; but each transferase produces a different isomer. These isomers can be separated by reversed-phase HPLC; thus, each enzyme can be identified from product analysis (41).

\section{Sugar Chain-Related Enzymes Which Recognize a Large Area of the Substrates \\ C-1. Cytosolic $\alpha$-Mannosidase}

Cytosolic $\alpha$-mannosidase has been purified from Japanese quail oviduct, rat liver, bovine liver, hen oviduct, and ginkgo seed (42-46). It acts on high-mannose type sugar chains and hydrolyzes $\alpha$-mannosyl linkages one by one from the non-reducing ends of the sugar chains. The enzyme is activated by a $\mathrm{Co}^{2+}$ ion, which changes its substrate specificity (47). In the case of cytosolic $\alpha$-mannosidases from mammals, the non-activated enzyme hydrolyzes M9A to produce M8C , whereas the $\mathrm{Co}^{2+}$ ion-activated enzyme hydrolyzes four $\alpha$-mannoside linkages of Man 1 1-2Man $\alpha 1-6$ (Man $\alpha 1$ 2Man $\alpha 1-3)$ Man $\alpha$ in M9A one by one to produce M5B as an end product (48) (Fig. 4). This hydrolysis does not depend
利用して小胞体およびゴルジ $\alpha$ - マンノシダーゼの基質特異性 が解析された。小胞体 $\alpha$-マンノシダーゼIによる M 9 A からマ ンノースのトリミングが M8A を経由して起こること (39)、そ の M8A がゴルジ $\alpha$ - マンノシダーゼIA あるいはIB のもっと も良い基質であること (40)が示された (図 3)。このことはこ れらのマンノシダーゼの基質特異性が相補的であることを示 している。そしてゴルジ $\alpha$-マンノシダーゼIA あるいはIB は M8Aの $\alpha-1,2-$ マンノシド結合を加水分解し、最終産物として M5A を与える (40)。

また、均一な基質を用いても酵素反応生成物が複数ある場 合があるが、HPLCでの保持時間から生成物の同定が行える。 例えば、N-アセチルグルコサミン転移酵素 III、IV、V は、Bi の マンノース残基に $N$-アセチルグルコサミンを転移し、各酵素 は生成物として異なる異性体を与える。それら異性体は逆相 HPLCにより分離でき、生成物の解析から酵素の同定を行える (41)。

\section{C. 基質の広い領域を認識する糖鎖関連醰素}

C-1. 細胞質 $\alpha$-マンノシダーゼ

細胞質 $\alpha$-マンノシダーゼはウズラ輸卵管、ラット肝臟、 ウシ肝臓、ニワトリ輸卵管、イチョウ種子などから精製され ている (42-46)。ハイマンノース型糖鎖に作用し、非還元末端 から一残基ずつマンノースを切断していく。 $\mathrm{Co}^{2+}$ イオン存在 下で酵素は活性化されるとともに、基質特異性も変化する(47)。 動物由来のものでは、 $\mathrm{Co}^{2+}$ イオンによる活性化前は $\mathrm{M} 9 \mathrm{~A}^{2}$ か ら M8C'を生成し、 $\mathrm{Co}^{2+}$ イオンによる活性化後は M9A'の Man $\alpha 1-2 M a n \alpha 1-6(M a n \alpha 1-2 M a n \alpha 1-3) M a n \alpha$ 部分の $4 \supset の \alpha-$ ンノシド結合を一残基ずつ加水分解し、最終産物として M5B' を生成する (48)(図 4)。この加水分解は結合位置によらず ( $\alpha 1-$ 2、 $\alpha 1-3 、 \alpha 1-6$ 結合が加水分解される)、この酵素の基質特異性 


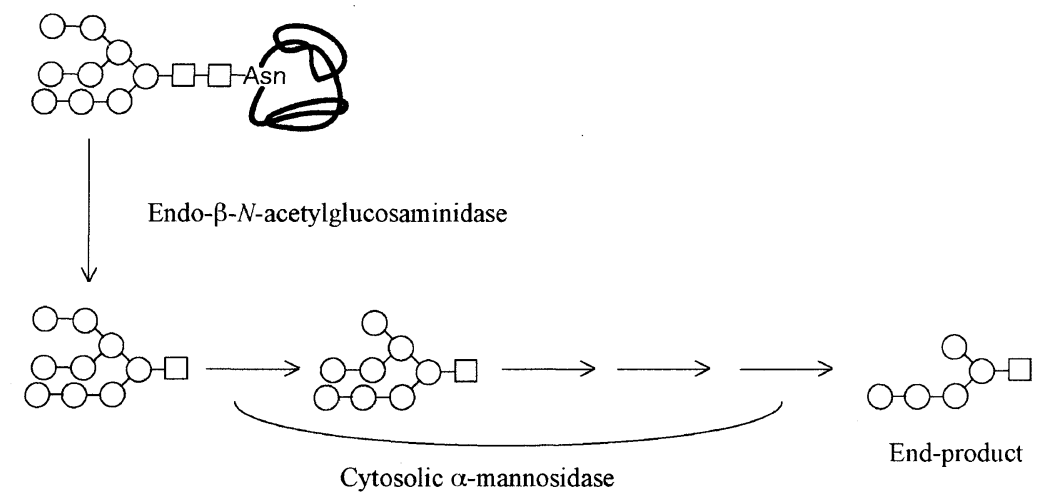

Fig. 4. Processing pathway of high-mannose type sugar chains by the co-operative action of endo$\beta$ - $N$-acetylglucosaminidase and cytosolic $\alpha$-mannosidase. Circles and squares represent mannose and $N$-acetylglucosamine residues, respectively. The bold line represents protein.

on the exact linkage positions (i.e. the $\alpha 1-2, \alpha 1-3$, and $\alpha 1-6$ linkages are hydrolyzed), showing that this enzyme has tolerant substrate specificity. By contrast, the other linkages are hardly hydrolyzed, showing that this enzyme also has strict substrate specificity.

Cytosolic $\alpha$-mannosidase also recognizes the reducing end of sugar chains: the bulkier the structure of the reducing end of sugar chain is, the lower its hydrolysis rate is (48). The hydrolysis rate against sugar chains bearing one GlcNAc residue at the reducing end is 4 to 16 times higher than that against sugar chains bearing $N, N$ '-diacetylchitobiose. Thus, cytosolic $\alpha$-mannosidase recognizes a large area of substrates including both the reducing end and the non-reducing end of M9A'. Sugar chains bearing one GlcNAc residue at their reducing end, which are good substrates of this enzyme, are generated by the action of endo- $\beta-N$-acetylglucosaminidase on glycoproteins. Therefore, cytosolic $\alpha$-mannosidase and endo$\beta-N$-acetylglucosaminidase, which is also located in cytosol (49), are considered to cooperatively hydrolyze the highmannose type sugar chains of glycoproteins to accumulate M5B in the cytosol (50-53).

\section{C-2. Endo- $\beta$ - $N$-Acetylglucosaminidase}

Endo- $\beta$ - $N$-acetylglucosaminidase hydrolyzes the glycosyl bond in $N, N$ '-diacetylchitobiose of $N$-linked sugar chains and liberates sugar chains from glycoproteins. The substrate specificity of this enzyme has been investigated using dansylated asparagine-linked and pyridylaminated sugar chains. Most enzymes discriminate high-mannose, hybrid, and complex type sugar chains, and recognize a large area of the substrate, including the sites of hydrolysis and the nonreducing ends of the sugar chains.

Endo- $\beta$ - $N$-acetylglucosaminidases from Aspergillus oryzae and Streptomyces griseus (Endo-H) hydrolyze highmannose and hybrid type sugar chains $(54,55)$. Each enzyme from Flavobacterium meningosepticum (Endo- $\mathrm{F}_{1}, \mathrm{~F}_{2}, \mathrm{~F}_{3}$ ) has a different substrate specificity. Endo- $F_{1}$ acts on high-
の寛容さを示している。一方、他の結合は切断されにくく、 基質特異性の厳密さも兼ね備えている。

この酵素は還元末端の構造も認識し、還元末端が蒿高く なるほど加水分解速度が低下する (48)。還元末端が GlcNAc-・ 残基の糖鎖に対する加水分解速度は GlcNAc 二残基の糖鎖に対 するものに対して、4 16 倍活性が高い。すなわち、細胞質 $\alpha$-マンノシダーゼは M9A'の還元末端部分、非還元末端部分 の両方を含む広い範囲を認識している。この酵素の基質とな る還元末端に GlcNAc を一残基のみもつ糖鎖は、糖タンパク質 にエンド- $\beta$ - $N$-アセチルグルコサミニダーゼが作用することに よって生成する。すなわち、細胞質 $\alpha$-マンノシダーゼは、同 じく細胞質に存在するエンド- $\beta-N$ - アセチルグルコサミニダー ゼ (49) と協同で糖タンパク質のハイマンノース型糖鎖を加水 分解し、最終産物の M5B' を細胞質に蓄積させると考えられる (50-53)。

\section{C-2. エンド- $\beta-N$ - アセチルグルコサミニダーゼ}

エンド- $\beta-N$-アセチルグルコサミニダーゼは $N$ - 配糖体の $N, N$ - ジアセチルキトビオース部分のグリコシド結合を加水分 解し、糖タンパク質から糖鎖を遊離する酵素である。この酵 素の基質特異性はダンシル化されたアスパラギンに結合した 糖鎖あるいはピリジルアミノ化糖鎖を用いて調べられている。 その多くはハイマンノース型、ハイブリッド型、コンプレッ クス型糖鎖を区別しており、加水分解部位のみならず、非還 元末端も含めた基質の広い範囲を認識している。

Aspergillus oryzae、Streptomyces griseus 由来エンド- $\beta-N-$ ア セチルグルコサミニダーゼ (Endo-H) は八イマンノース型、八 イブリッド型糖鎖を基質とする $(54 、 55)$ 。Flavobacterium meningosepticum に存在する 3 種類の酵素 $\left(\right.$ Endo- $\mathrm{F}_{1} 、 \mathrm{~F}_{2} 、 \mathrm{~F}_{3}$ ) はそれぞれ 異なる基質特異性を持ち、 $\mathrm{F}_{1}$ はハイマンノース型、ハイブリッ ド型糖鎖に、 $\mathrm{F}_{2}$ は八イマンノース型、バイアンテナ型糖鎖に、 $\mathrm{F}_{3}$ はバイアンテナ、トリアンテナ型糖鎖に作用する $(56.57)$ 。 
mannose and hybrid type sugar chains, endo- $\mathrm{F}_{2}$ acts on highmannose type and biantennary sugar chains, and endo- $\mathrm{F}_{3}$ acts on biantennary and triantennary sugar chains $(56,57)$. The minimum structure of the substrates of endo- $\mathrm{H}$ and endo- $\mathrm{F}_{1}$ is M3C (56). The enzymes from Arthrobacter protophormiae and Clostridium perfringens (Endo-A, $\mathrm{C}_{\mathrm{II}}$ ) hydrolyze highmannose type sugar chains $(58,59)$. The enzyme from Streptococcus pneumoniae (Endo-D) recognizes high-mannose and hybrid type sugar chains, and its minimum recognition unit is M3B (60). This enzyme strictly discriminates between M5A and M6B, and acts on M5A but not M6B (60). Endo- $C_{I}$ from $C$. perfringens has the same specificity (59). By contrast, the enzymes from plants (61-64) and hen oviduct (65) act preferentially on M6B rather than M5A, suggesting that these enzymes recognize the Man $\alpha 1-2 \mathrm{Man} \alpha 1-3 \mathrm{Man} \beta$ structure. The enzyme from human saliva (Endo-HS) specifically hydrolyzes complex type sugar chains (66), whereas the enzyme from Mucor hiemalis (Endo-M) has wide substrate specificity and hydrolyzes high-mannose, hybrid, and complex type sugar chains $(67,68)$.

In summary, endo- $\beta-N$-acetylglucosaminidases have highly variable substrate specificity. All of the enzymes recognize a large area of the sugar chains. They recognize the hydrolysis site near the reducing ends of sugar chains strictly, but whereas they recognize the non-reducing ends of sugar chains with a tolerance that is characteristic of the enzyme.

\section{C-3. Endo- $\beta$-mannosidase}

Endo- $\beta$-mannosidase, which hydrolyzes the Man $\beta 1$ 4GlcNAc linkage of $N$-linked sugar chains, was discovered in plant tissue (69). When Man $\alpha 1-6$ Man $\beta 1-4$ GlcNAc $\beta 1$ 4GlcNAc-PA (PA, pyridylamino group) was used as a substrate for the enzyme, Man $\alpha 1-6 \mathrm{Man}$ and GlcNAc $\beta 1$ 4 GlcNAc-PA were produced. Unlike $\beta$-mannosidase and endo- $\beta$-mannanase, endo- $\beta$-mannosidase does not hydrolyze $p$-nitorophenyl $\beta$-mannoside and $\beta 1,4$-mannohexaose; therefore, this enzyme activity can be detected only by using $N$-linked sugar chains as substrates (69).

Endo- $\beta$-mannosidase can recognize not only the site of hydrolysis, namely the Man $\beta$ linkage, but also the Man $\alpha 1$ $6 \mathrm{Man} \beta$ linkage and the 2-OH and 3-OH groups of $\mathrm{Man} \beta$ (6971). The hydrolysis rate of the enzyme against glycopeptides has been found to be faster than that against the corresponding sugar chains, meaning that the enzyme has affinity for the peptide portion of glycopeptides (71). In other words, endo$\beta$-mannosidase has the ability to recognize a large area of the substrate.

Endo- $\beta$-mannosidase does not act on the sugar chains bearing a Man $\alpha 1-3 \operatorname{Man} \beta$ linkage. This substrate specificity is therefore complementary to that of jack bean $\alpha$-mannosidase, which hydrolyzes a Man $\alpha 1-3 \operatorname{Man} \beta$ linkage preferably to a Man $\alpha 1-6$ Man $\beta$ linkage $(36,72,73)$. Endo- $\beta$-mannosidase
Endo-H, $\mathrm{F}_{1}$ の基質の最小単位は M3C である (56)。Arthrobacter protophormiae、Clostridium perfringens 由来酵素 (Endo-A, $\mathrm{C}_{11}$ ) は ハイマンノース型糖鎖を認識し、加水分解する (58、59)。Streptococcus pneumoniae 由来エンド- $\beta$ - $N$ - アセチルグルコサミニ ダーゼ (Endo-D) はハイマンノース型、ハイブリッド型糖鎖を 認識し、必要最小単位は M3Bである (60)。この酵素はM5A と M6B を厳密に区別し、M5A には作用するが、M6Bには作 用しない (60)。Endo-C $C_{1}$ でも同様の特異性が見られる (59)。逆 に植物由来の酵素 (61-64) やニワトリ輸卵管由来の酵素 (65) はM5A よりも M6B に作用しやい。すなわちこれらはMana1$2 \mathrm{Man} \alpha 1-3 \mathrm{Man} \beta$ 部分を認識している。コンプレックス型糖鎖 に特異的に働くヒト唾液由来エンド- $\beta$ - $N$-アセチルグルコサミ ニダーゼ(Endo-HS)(66) も知られている。Mucor hiemalis 由来 酵素 (Endo-M) は広い基質特異性を有し、ハイマンノ一ス型、 ハイブリッド型、コンプレックス型のいずれにも働く $(67,68) 。$

これら一群のエンド- $\beta-N$-アセチルグルコサミニダーゼは その基質特異性に多様性があるが、いずれも基質の広い領域 を認識している。そして、還元末端は厳密に、非還元末端は それぞれの酵素に特有の寛容さを持って、基質を認識してい る。

\section{C-3. エンド- $\beta$ - マンノシダーゼ}

$N$ - 配糖体の Man $\beta 1-4 G l c N A c$ 結合をエンド型で加水分解す るエンド- $\beta$-マンノシダーゼが植物組織より見いだされた(69)。

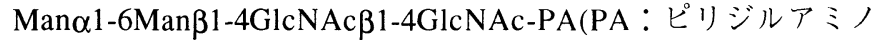
基) を基質としたとき、Man $\alpha 1-6 \mathrm{Man}$ と GlcNAc $\beta 1-4 \mathrm{GlcNAc}$ $\mathrm{PA}$ を生成する。本酵素は $\beta$ - マンノシダーゼやエンド- $\beta$ - マン ナナーゼとは異なり、パラニトロフェニル $\beta$-マンノシドに対 しても $\beta 1,4$ - マンノヘキサオースに対しても活性がなく、 $N$ - 配 糖体糖鎖を用いて初めて活性の検出が可能となった $(69)$ この 酵素は加水分解部位の Man $\beta$ 結合に加えて、Man $\alpha 1-6 \operatorname{Man} \beta$ 扮 よびMan $\beta$ の 2 位、 3 位の水酸基を認識している (69-71)。ま た糖ぺプチドに対する加水分解速度が対応する糖鎖に対する ものより速いことから、酵素は糖ぺプチドのペプチド部分に 親和性がある (71)。すなわちエンド - $\beta$-マンノシダーゼも糖鎖 の非還元末端から還元末端まで広い領域を認識している

この酵素は Man $\alpha 1-3 \operatorname{Man} \beta$ 結合をもつ糖鎖には作用しない この基質特異性は Man $\alpha 1-6 \operatorname{Man} \beta$ 結合よりもMan $\alpha 1-3 \operatorname{Man} \beta$ 結 合によく作用する jack bean $\alpha$ - マンノシダーゼの基質特異性 (36、72、73) と相補的になっている。すなわち植物細胞中で、工 


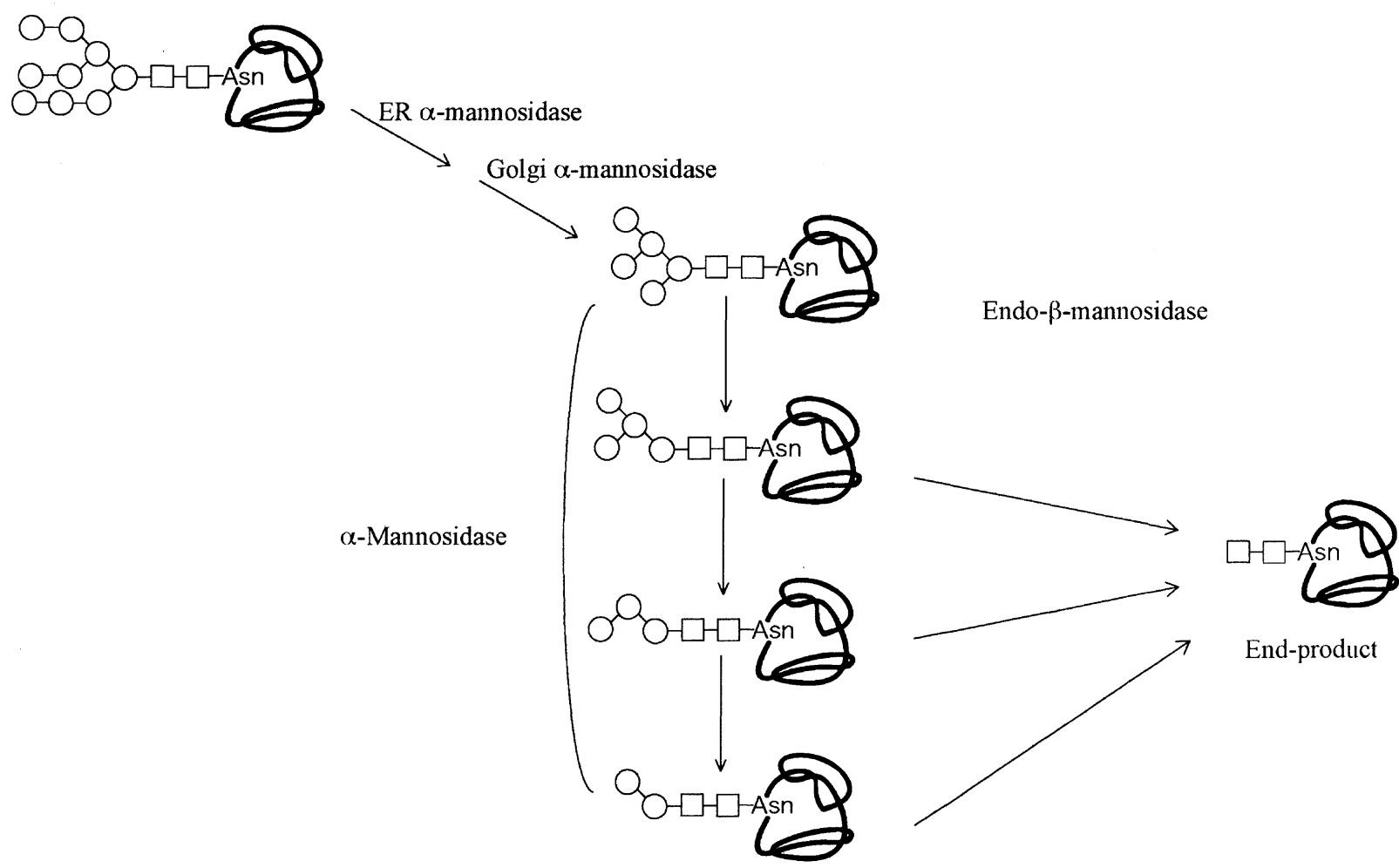

Fig. 5. Processing pathway of high-mannose type sugar chains by the co-operative action of jack bean $\alpha$-mannosidase-like enzyme and endo- $\beta$-mannosidase. Circles and squares represent mannose and $\mathrm{N}$-acetylglucosamine residues, respectively. The bold line represents protein.

and jack bean $\alpha$-mannosidase-like enzyme are considered to cooperatively hydrolyze high-mannose type sugar chains on glycoproteins in a plant cell to generate glycoproteins bearing chitobiose $(70,74)$ (Fig. 5). Endo- $\beta$-mannosidase has strict substrate specificity in that it does not hydrolyze the $\operatorname{Man} \beta$ linkages of sugar chains bearing a Man $\alpha 1-3 \operatorname{Man} \beta$ linkage; however, it also has tolerant substrate specificity as it can hydrolyze the Man $\beta$ linkages of sugar chains that do not have the Man $\alpha 1-3$ Man $\beta$ linkage.

\section{C-4. Glycosyltransferases}

Analysis of the substrate specificities of glycosyltransferases by using several homogeneous sugar chains has been rarely carried out. Of the glycosyltransferases that have been analyzed for substrate specificity, three enzymes that recognize a large area of the sugar chains are described below.

$\mathrm{N}$-acetylglucosaminyltransferase V transfers $\mathrm{N}$-acetylglucosamine to the Man $1-6$ residue of the Bi sugar chain via a $\beta 1-6$ linkage. Its substrate specificity has been investigated using pyridylaminated sugar chains. The enzyme prefers $\mathrm{Bi}$ and Tri: the reaction rate against sugar chains bearing core fucose (Fuc $\alpha 1-6 \mathrm{GlcNAc}$ ) was found to be $20 \%$ lower than that against $\mathrm{Bi}$ and Tri (75). Thus, it seems that the structure of the reducing end of the sugar chain, in addition to the site of glycosyl transfer, influences enzyme activity.
ンド- $\beta$ - マンノシダーゼと jack bean $\beta$ - マンノシダーゼ様醳素 が協同で働いて、糖タンパク質上のハイマンノース型糖鎖を 加水分解し、最終産物としてキトビオースを持つタンパク質 を生成すると考えられる(70、74)(図 5)。エンド- $\beta$ ○マンンノダー ゼもMan $\alpha 1-3 \operatorname{Man} \beta$ 結合をもつ糖鎖には作用しない厳密な特異 性と Man $\alpha 1-3 M a n \beta$ 結合をもたない糖鎖であれば加水分解する というやわらかい特異性を有している。

\section{C-4. 糖転移酵素}

一連の均一な糖鎖基質を用いた糖転移酵素の基質特異性 解析はあまり行われていない。基質特異性解析が行われた醅 素のうち、糖鎖基質の広い領域を認識する 3 つの糖転移醉素 について、以下に述べる。

$N$ - アセチルグルコサミン転移酵素 V は Bi の Manal-6 に $\beta 1$-6 結合で $N$-アセチルグルコサミンを転移する酵素である。 一連のピリジルアミノ化糖鎖で基質特異性が調ベられ、Biや Tri をよい基質とし、還元末端の GlcNAcにFuc $\alpha 1$-6が結合し ているとその活性は $20 \%$ ほど低下した (75)。糖転移される部 位に加え、還元末端近傍の構造も酵素活性に影響を及ぼして いると考えられる。 
The $\beta 1$,4-galactosyltransferase expressed in mouse brain, unlike the enzyme expressed in other organs, transfers galactose to the GlcNAc residue at the non-reducing end of $\mathrm{Bi}, \mathrm{BiF}$ and $\mathrm{BiB}$, but not $\mathrm{BA}-2$ (76). BA-2 is a competitive inhibitor of this enzyme. These facts correspond to the fact that BA-1 and BA-2 are specifically expressed in brain tissues (77). The transfer activity against $\mathrm{BiB}$ is relatively low, showing that the bisecting GlcNAc affects the transfer reaction. This enzyme also recognizes sugar chains from their reducing end to their non-reducing end, although it is necessary to take into account the difference in the threedimensional structures of the sugar chains.

The backbone of pectic polysaccharides in the plant cell wall is polygalacturonic acid, a homopolymer of $\alpha-1,4$-linked galacturonic acid. The substrate specificity of polygalacturonic acid synthase (polygalacturonic acid: $\alpha 1-$ 4 galacturonosyltransferase) has been investigated using pyridylaminated oligogalacturonic acids, (GalUA) n $^{-}$PA (78). The transfer activity against shorter sugar chains, (GalUA $)_{5 \sim 10^{-}}$ $\mathrm{PA}$, was found to be relatively low, whereas that against longer sugar chains, (GalUA) $)_{11 \sim 14}$-PA, was relatively high. Of the substrates investigated, the best was found to be (GalUA) $)_{14}$-PA. This enzyme also recognizes a wide area of the sugar chains, although the tertiary structure of each (GalUA) $)_{n}-\mathrm{PA}$ is not known.

\section{Concluding Remarks}

Analysis of the substrate specificity of sugar chainrelated enzymes using large sugar chains can identify the novel substrate specificity of an enzyme. This type of analysis can also elucidate the functions of the enzymes beyond the level of categorization of the enzymes by their substrate specificity. A detailed analysis of substrate specificity will be essential for functional glycobiology studies that aim to elucidate the function of sugar chains and their related enzymes in vivo, although practical examples of such analyses are still few. This analysis revealed that pairs of enzymes with complementary substrate specificities cooperatively hydrolyze the sugar chains. These pairs include ER $\alpha$-mannosidase I and Golgi $\alpha$-mannosidase I (Fig. 3), cytosolic $\alpha$-mannosidase and endo- $\beta$ - $N$-acetylglucosaminidase (Fig. 4), and endo- $\beta$ mannosidase and jack bean $\alpha$-mannosidase-like enzyme (Fig. 5). The functional analysis of these pairs can be furthered by analyzing the localization of these enzymes in a cell and by biochemical analysis (e.g. each of these pairs may form a protein complex.).

Although analyses of substrate specificity using synthetic glycopeptides have been hardly carried out, they will also play a role in glycobiology. One of the target enzymes for these analyses is protein $O$-fucosyltransferase 1 (OFUT1), which transfers fucose to a consensus sequence in the EGF-
マウス脳に存在する $\beta 1,4-$ ガラクトース転移酵素は、他の 臟器に存在する酵素とは違い、Bi、BiF、BiB の非還元末端の GlcNAc にガラクトースを転移するが、BA-2 にはガラクトー スを転移しない $(76)$ 。転移が見られない BA-2 は本酵素の競争 阻害剂になる。このことは BA-1 および BA-2が脳に特異的に 存在する (77) という実験事実と一致する。BiBに対する転移 活性は低く、バイセクティング GlcNAc が存在すると転移反応 が抑えられる。これら各糖鎖の立体構造の違いを考慮に入れ る必要があるが、本酵素も還元末端から非還元末端まで広い 範囲を認識している。

植物細胞壁のペクチン主骨格はガラクッロン酸が $\alpha 1-4$ 結 合で連なったポリガラクッロン酸からなっている。その合成 を担うポリガラクッロン酸合成酵素 (ポリガラクッロン酸： Q1-4 ガラクッロン酸転移酵素) についてピリジルアミノ化才 リゴガラクッロン酸、(GalUA) $-\mathrm{nA}$ 、を用いて基質特異性が調 べられている (78)。(GalUA) $)_{5-10}-\mathrm{PA} の$ 短い糖鎖に対する転移活 性は比較的低く、より重合度の大きい (GalUA) $11-14-\mathrm{PA}$ に対亦 る活性が高い。調べた中では (GalUA) $)_{14}$-PAをもっともよい基 質とした。重合度が違う (GalUA) - -PAの明確な三次元構造情 報はないが、この酵素は明らかに基質の広い範囲を認識して いる。

\section{D. 終わりに}

糖鎖関連酵素の基質特異性解析は、天然のものに近い大 きな基質を用いることにより、新しい活性が見えてくる可能 性がある。またそれは酵素を基質特異性によって分類すると いう次元を越えて、それぞれの酵素の生体内での役割解明に 迫る。詳細な基質特異性解析はまだ例が少ないが、糖鎖や糖 鎖関連酵素の生体内での意味づけを行う機能糖鎖生物学に欠 かせないものになってくるであろう。基質特異性解明により、 小胞体 $\alpha$-マンノシダーゼIとゴルジ $\alpha$-マンノシダーゼI ( 図 3)、 細胞質 $\alpha$-マンノシダーゼとエンド- $\beta-N-$ - セチルグルコサミ ニダーゼ (図 4)、エンド- $\beta$-マンノシダーゼと jack bean $\alpha$ - マ ンノシダーゼ様酵素 (図 5)、それぞれの組み合わせにおいて、 基質特異性が相補的で、これらが協同で働き、糖鎖の加水分 解が行われていることが明らかになった。これらの成果を元 に、それぞれの組み合わせにおいての細胞内の局在や発現パ ターン、生化学的な解析 (タンパク質複合体を作っていること も考えられる)を通して、機能解明指向性の研究を進めていく ことができる。

均一な合成糖ぺプチドを用いた基質特異性解析はまだほ とんど行われていないが、今後糖鎖生物学で重要な位置を占 めてくると思われる。Notchの EGF 様ドメインのあるコンセ ンサス配列上に存在するフコースを転移する OFUT1 を例に 
like domain of Notch. It has been reported that OFUT 1 facilitates the folding of Notch (79), implying that OFUT1 has an affinity for Notch protein; however, its biochemical analysis has not yet been carried out. Current techniques permit synthesis of an EGF-like domain peptide with fucose attached, and future studies should aim to analyze the substrate specificity of OFUT1 using the EGF-like domain of Notch with or without fucose.

The crystal structure of a hen egg lysozyme and tri$\mathrm{N}$-acetylchitotriose complex has been solved, leading to the model structure of a lysozyme-hexa- $N$-acetylchitohexaose complex (80). Since then, it has been generally accepted that the sugar chain-related enzymes are associated with sugar chains such as hexasaccharides. However, data showing that these enzymes associate with hexasaccharides or larger saccharides has not been produced. In this article, we have described several sugar chain-related enzymes that recognize sugar chains such as hexasaccharides or decasaccharides. The enzymes recognize a large part of the primary structure of the sugar chains, however, data showing how wide an area of the enzyme is involved in substrate recognition are still lacking. With the current progress in structural biology, we hope that further tertiary structural analyses of the enzyme-sugar chain complexes will be carried out.

Analysis of the substrate specificity of sugar chainrelated enzymes has also revealed that there are few enzymes that recognize only one substrate, but there are many enzymes that give one end product. As such, functional analysis of the end product in a cell must be carried out. The production of an end product is based on unique characteristics of the sugar chain-related enzymes, which recognize a part of the substrate strictly, and another part of the substrate tolerantly. Tolerant recognition of the sugar chain-related enzymes seems to be a strategy whereby enzymes respond to the microheterogeneity of sugar chains. It appears that this property of substrate recognition by the sugar chain-related enzymes symbolizes living organisms, which are also characterized by their strictness and tolerance. Functional analysis of the sugar chain-related enzymes and/or the sugar chains may provide insight into living organisms with strict and tolerant characters, a feature that has hardly been revealed by molecular biology.
挙げる。OFUT1 に基質の Notch タンパク質のフォールディン グを助ける働きがあるという (79)。これは OFUT1 がNotch と 親和性があることも意味しているが、生化学的な解析はなさ れていない。現在の技術ではフコースが結合した EGF様ドメ インの合成が可能になってきており、Notch 中の EGF 様ドメ インあるいはフコースが結合した EGF 様ドメインを用いた OFUT1 の基質特異性解析が待たれる。

リゾチームとトリ $N$-アセチルキトトライオース複合体の 結晶構造が解かれ、ヘキサ $N$-アセチルキトへキサオースとの 複合体のモデル構造が提出されて以来 $(80) 、$ 糖鎖関連酵素が 6 糖程度の糖鎖と相互作用している、という考えが一一般的に 受け入れられている感がある。しかし実際に糖鎖関連酵素が 6 糖以上の糖鎖を認識していることを示すデー夕はほとんと 蓄積されていない。本稿では複数の糖鎖関連酵素が5、6 糖あ るいは 10 糖の単位で糖鎖を区別して基質を認識していること を紹介した。糖鎖関連酵素が基質の一次構造上、広い領域を 認識しているとは言っても、酵素あるいは糖鎖基質との複合 体の立体構造情報が不足しており、酵素のどれくらいの領域 が基質認識に関わっているか、示せるデー夕はほとんどない 現在の構造生物学の進渉に伴って、これらの立体構造解析が 進むことが期待される。

基質特異性解析により、一基質しか認識しないというよう な糖鎖関連酵素は少ないが、一つの構造の最終産物を与える 酵素がある、ことも明らかになってきた。その最終産物の機 能解析が待たれる。これは、ある部分は厳密に認識し、ある 部分の認識には寛容である、という糖鎖関連酵素のユニーク な性質に基づく。ある部分の認識に寛容であるのは、糖鎖の 不均一性にも対応するかのような糖鎖関連酵素の戦略である ようにも思える。糖鎖関連酵素の基質認識能は、堅さ、やわ らかさを兼ね備える生物を象徴しているようであり、糖鎖の 機能解析はこれまでに分子生物学によって示されることが少 なかった生物らしさに迫るものになるかもしれない。

\section{References}

1. Enzyme Nomenclature 1992 of IUBMB. Academic Press, New York, 1992

2. Henrissat, B. (1991) Biochem. J. 280, 309-316

3. Ito, Y., and Ohnishi, Y. (2001) In Glycoscience: chemistry and chemical biology. (Fraser-Reid, B.O., Tatsuta, K., and Thiem, J. eds.) Springer-Verlag, Berlin, pp. 1589-1619

4. Hojo, H., and Nakahara, Y. (2000) Curr. Protein Pept. Sci. 1, 23-48

5. Nakahara, Y. (2003) Trends Glycosci. Glycotech. 15, 257-273

6. Nakahara, Y., Nakahara, Y., and Ogawa, T. (1996) Carbohydr. Res. 292, 71-81

7. Takano, Y., Habiro, M., Someya, M., Hojo, H., and Nakahara, Y. (2002) Tetrahedron Lett. 43, 8395-8399

8. Hojo, H., Haginoya, E., Matsumoto, Y., Nakahara, Y. Nabeshima, K. Toole, B.P., and Watanabe, Y. (2003) Tetrahedron Lett. 44, 2961-2964 
9. Otvos, L.J., Urge, L., Hollosi, M., Wroblewski, K., Graczyk, G., Fasman, G.D., and Thurin, J. (1990) Tetrahedron Lett. 31, 5889-5892

10. Reimer, K.B., Meldal., M., Kusumoto, S., Fukase, K., and Bock, K. (1993) J. Chem. Soc. Perkin Trans. 1, 925-932

11. Ichiyanagi, T., Takatani, M., Sakamoto, K., Nakahara, Y., Ito, Y., Hojo, H., and Nakahara, Y. (2002) Tetrahedron Lett. 43, 3297-3300

12. Xue, J., and Guo, Z. (2003) J. Org. Chem. 68, 2713-2719

13. Seitz, O., and Wong, C.H. (1997) J. Am. Chem. Soc. 119, 8766-8776

14. Gobbo, M., Biondi, L., Filira, F., Gennaro, R., Benincasa, M., Scolaro, B., and Rocchi, R. (2002) J. Med. Chem. 45. $4494-4504$

15. Takemura, T., Hojo, H., Nakahara, Y., Ishimizu, T., and Hase, S. (2004) Org. Biomol. Chem. 2, 133-136

16. Kitamura, M., Hojo, H., Nakahara, Y., Ishimizu, T., and Hase, S. (2004) Glycoconj. J. 21, 197-203

17. Mizuno, M., Haneda, K., Iguchi, R., Muramoto, I., Kawakami, T., Aimoto, S., Yamamoto, K., and Inazu, T. (1999) J. Am. Chem. Soc. 121. 284-290

18. Seko, A., Koketsu, M, Nishizono, M, Enoki, Y., Ibrahim, H.R., Juneja, L.R., Kim, M., and Yamamoto, T. (1997) Biochim. Biophys. Acta. 1335, 23-32

19. Yamamoto, N., Ohmori, Y., Sakakibara, T., Sasaki, K., Juneja, L.R., and Kajihara, Y. (2003) Angew. Chem. Int. Ed. 42, 2537-2540

20. Kajihara, Y., Suzuki, Y., Yamamoto, N., Sasaki, K., Sakakibara, T., and Juneja, L.R. (2004) Chem. Eur. J. 10, 971-985

21. Kajihara, Y., Yamamoto, N., Miyazaki, T., and Sato, H. (2005) Curr. Med. Chem. 12, 527-550

22. Hase, S., Nishimura, H., Kawabata, S., Iwanaga, S., and Ikenaka, T. (1990) J. Biol. Chem. 265, 1858-1861

23. Hase, S., Ikenaka, T., and Matsushima, Y. (1978) Biochem. Biophys. Res. Commun. 85, 257-263

24. Hase, S. (1994) Methods Enzymol. 230, 225-237

25. Natsuka, S., and Hase, S. (1998) Methods Mol. Biol. 76, 101-113

26. Ohta, M., Hamako, J., Yamamoto, S., Hatta, H., Kim, M., Yamamoto, T., Oka, S., Mizouchi, T., and Matsuura, F. (1991) Glycoconj. J. 8, 400-413

27. Tarutani, M., Norioka, N., Mega, T., Hase, S., and Ikenaka, T. (1993) J. Biochem. 113, 677-682

28. Hase, S., Okawa, K., and Ikenaka, T. (1982) J. Biochem. 91, 735-737

29. Yamaguchi, H., Ikenaka, T., and Matsushima, Y. (1971) J. Biochem. 70, 587-594

30. Minobe, S., Nakajima, H., Itoh, N., Funakoshi, I., and Yamashina, I. (1979) J. Biochem. 86, 1851-1854

31. Rice, K.G., Rao, N.B.N., and Lee, Y.C. (1990) Anal. Biochem. 181, 249-258

32. Hase, S., Ikenaka, K., Mikoshiba, K., and Ikenaka, T. (1988) J. Chromatogr. 434, 51-60

33. Yanagida, K., Ogawa, H., Omichi, K., and Hase, S. (1998) J. Chromatogr.A. 800, 187-198

34. Tomiya, N., and Takahashi, N. (1998) Anal. Biochem. 264, 204-210

35. Hase, S., Natuska, S., Oku, H., and Ikenaka, T. (1987) Anal. Biochem. 167, 321-326

36. Oku, H., Hase, S., and Ikenaka, T. (1990) Anal. Biochem. 185, 331-334

37. Dorland, L., van Halbeek, H., Vliegenthart, J.F.G., Lis, H., and Sharon, N. (1981) J. Biol. Chem. 256, 7708-7711

38. Mutsaers, J.H.G.M., van Halbeek, H., Vliegenthart, J.F.G., Iwase, H., Kato, Y., and Hotta, K. (1985) Biochim. Biophys. Acta. 843, 12312737.

39. Gonzalez, D.S., Karaveg, K., Vandersall-Narin, A.S., Lal, A., and Moremen, K.W. (1999) J. Biol. Chem. 274, 21375-21386

40. Lal, A., Pang, P., Kalelkar, S., Romero, P.A., Herscovics, A., and Moremen, K.W. (1998) Glycobiology 8, 981-995

41. Nishikawa, A., Gu, J., Fujii, S., and Taniguchi, N. (1990) Biochim. Biophys. Acta. 1035, 313-318

42. Oku, H., Hase, S., and Ikenaka, T. (1991) J. Biochem. 110, 29-34

43. Grard, T., Saint-Pol, A., Haeuw, J.-F., Alonso, C., Wieruszeski, J.-M., Strecker, G., and Michalski, J.-C. (1994) Eur. J. Biochem. 223, 99106

44. Kumano, M., Omichi, K., and Hase, S. (1996) J. Biochem. 119, 991-997

45. Yamashiro, K., Itoh, H., Yamagishi, M., Natsuka, S., Mega, T., and Hase, S.(1997) J. Biochem. 122, 1174-1181

46. Woo, K.K., Miyazaki, M., Hara, S., Kimura, M., and Kimura, Y. (2004) Biosci. Biotechnol. Biochem. 68, 2547-2556

47. Yamagishi, M., Ishimizu, T., Natsuka, S., and Hase, S. (2002) J. Biochem. 132, 253-256

48. Oku, H., and Hase, S. (1991) J. Biochem. 110, 982-989

49. Suzuki, T., Kitajima, K., Inoue, S., and Inoue Y. (1995) Glycoconj. J. 12, 183-193

50. Moore, S.E., and Spiro, R.G. (1994) J. Biol. Chem. 269, 12715-12721

51. Kmiécik, D., Herman, V., Stroop, C.J.M., Michalski, J.-C., Mir, A.-M., Labiau, O., Verbert, A., and Cacan, R. (1995) Glycobiology 5, 483494

52. Iwai, K., Mega, T., and Hase, S. (1999) J. Biochem. 125, 70-74

53. Ohashi, S., Iwai, K., Mega, T., and Hase, S. (1999) J. Biochem. 126, 852-858

54. Tarentino, A.L., and Maley, F. (1974) J. Biol. Chem. 249, 811-817

55. Hitomi, J., Murakami, Y., Saitoh, F., Shigemitsu, N., and Yamaguchi, H. (1985) J. Biochem. 98, 527-533

56. Trimble, R.B., and Trentino, A.L. (1991) J. Biol. Chem. 266, 1646-1651

57. Plummer, Jr., T.H., and Tarentino, A.L. (1991) Glycobiology 1, 257-263

58. Takegawa, K., Nakoshi, M., Iwahara, S., Yamamoto, K., and Tochikura, T. (1989) Appl. Environ. Microbiol. 55, $3107-3112$

59. Ito, S., Muramatsu, T., and Kobata, A. (1975) Arch. Biochem. Biophys. 171, 78-86

60. Tai, T., Yamashita, K., Ogata-Arakawa, M., Koide, N., Muramatsu, T., Iwashita, S., Inoue, Y., and Kobata, A. (1975) J. Biol. Chem. 250, 8569-8575

61. Kimura, Y., Iwata, K., Sumi, Y., and Takagi, S. (1996) Biosci. Biotech. Biochem. 60, 228-232

62. Kimura, Y., Matsuo, S., and Takagi, S. (1998) Biosci. Biotech. Biochem. 62, 253-261

63. Kimura, Y., Tokuda, T., Ohno, A., Tanaka, H., and Ishiguro, Y. (1998) Biochim. Biophys. Acta 1381, 27-36

64. Kimura, Y., Matsuo, S., Tsurusaki, S., Kimura, M., Hara-Nishimura, I., Nishimura, M. (2002) Biochim. Biophys. Acta 1570, 38-246

65. Kato, T., Hatanaka, K., Mega, T., and Hase, S. (1997) J. Biochem. 122, 1167-1173

66. Ito, K., Okada, Y., Ishida, K., and Minamiura, N. (1993) J. Biol. Chem. 268, 16074-16081

67. Yamamoto, K., Kadowaki, S., Fujisaki, M., Kumagai, H., and Tochikura, T. (1994) Biosci. Biotech. Biochem. 58, 72-77 
68. Yamamoto, K. (1994) J. Biochem. 116, 229-235

69. Sasaki, A., Yamagishi, M., Mega, T., Norioka, S., Natsuka, S., and Hase, S. (1999) J. Biochem. 125, 363-367

70. Ishimizu, T., Sasaki, A., Okutani, S., Maeda, M., Yamagishi, M., and Hase, S. (2004) J. Biol. Chem. 279, 38555-38562

71. Sasaki, A., Ishimizu, T., and Hase, S. (2005) J. Biochem. 137, 87-93

72. Maley, F., and Trimble, R.B. (1981) J. Biol. Chem. 256, 1088-1090

73. Berman, E., and Allerhand, A. (1981) J. Biol. Chem. 256, 6657-6662

74. Ishimizu, T., Mitsukami, Y., Shinkawa, Y., Natsuka, S., Hase, S., Miyagi, M., Sakiyama, F., and Norioka, S. (1999) Eur. J. Biochem. 263, 624-634

75. Gu, J., Nishikawa, A., Tsuruoka, N., Ohno, M., Yamaguchi, N., Kangawa, K., and Taniguchi, N. (1993) J. Biochem. 113, 614-619

76. Nakakita, S., Menon, K.K., Natsuka, S., Ikenaka, K., and Hase, S. (1999) J. Biochem. 126, 1161-1169

77. Shimizu, H., Ochiai, K., Ikenaka, K., Mikoshiba, K., and Hase, S. (1993) J. Biochem. 114, 334-338

78. Akita, K., Ishimizu, T., Tsukamoto, T., Ando, T., and Hase, S. (2002) Plant Physiol. 130, 374-379

79. Okajima, T., Xu, A., Lei, L., and Irvine, K.D. (2005) Science 307, 1599-1603

80. Blake, C.C.F., Johnson, L.N., Mair, G.A., North, A.C.T., Phillips, D.C., and Sarma, V.R. (1967) Proc. R. Soc. London B 167, 378-388

Received on May 30, 2005, accepted on July 4, 2005

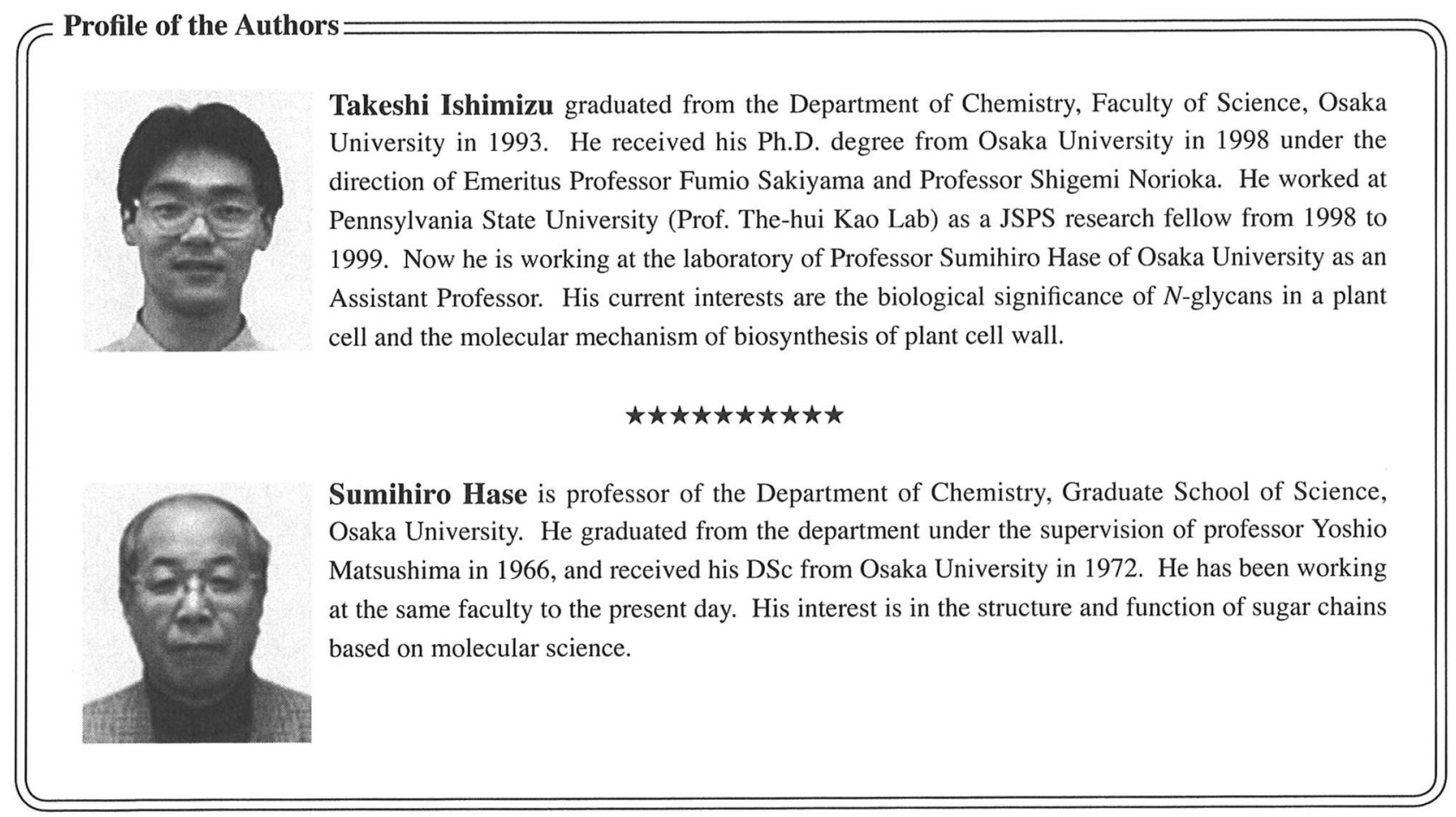

